\title{
Homeobox Protein Hox-A10
}

National Cancer Institute

\section{Source}

National Cancer Institute. Homeobox Protein Hox-A10. NCI Thesaurus. Code C26309.

Homeobox protein Hox-A10 (410 aa, $42 \mathrm{kDa}$ ) is encoded by the human HOXA10 gene.

This protein plays a role in embryonic pattern formation. 